\title{
The Relationship between Person Organization Fit, Person-Job-Fit and Turnover Intention in Banking Sector of Pakistan: The Mediating Role of Psychological Climate
}

\author{
Dr. Masood Ul Hassan \\ Department of Commerce, Bahauddin Zakariya University, Multan, Pakistan \\ E.mail: masoodulhassan99@gmail.com \\ Ammara Akram (Corresponding author) \\ Department of Commerce, Bahauddin Zakariya University, Multan,Pakistan \\ E.mail: ammara.akram1@gmail.com
}

Sana Naz

E.mail:blueocean_2407@yahoo.com

Department of Commerce, Bahauddin Zakariya University, Multan, Pakistan

Accepted: August 28, 2012 Published: September 29, 2012

Doi:10.5296/ijhrs.v2i3.2286 URL: http://dx.doi.org/10.5296/ijhrs.v2i3.2286

\begin{abstract}
In last few decades, employees' job related attitudes and behaviors have remained topics of considerable interest in the fields of organizational behavior and human resource management. This study aims to explore the impact of person-organization-fit and person-job-fit on employee turnover intention while considering psychological climate as a mediating variable. Sample for this research is consisted of 260 employees from top five commercial banks of large cities of Pakistan. SPSS 17 is used for analyzing the data. Correlation and regression analysis is used to test the direct and mediating relationship between key variables. Results indicate that both person-organization-fit and person-job-fit have negative relationship with turnover intention. Psychological climate partially mediates the relationship between person-organization-fit and turnover intention while fully mediates
\end{abstract}


the relationship between person-job-fit and turnover intention.

Keywords: Person-organization-fit, Person-job-fit, Psychological climate, Turnover intention.

\section{Introduction}

Human resource management plays vital role in developing employee skills, aptitude, knowledge and abilities to augment their work and organizational performance. The effective functioning of any organization not only depends on its available technical resources, but also on the eminence and competence of the employees which are required by the organization to fill its future human resource needs. Therefore, scholars in the field of organizational behavior and human resource management have shown great interest in the concept of Person-Environment P-E fit. P-E fit can be defined as the extent to which a person is compatible with the environment in which he or she is working (Dawis, 1992; Edwards, Caplan, \& Harrison, 1998). The concept of P-E fit includes Person-Vocation (P-V) fit, Person-Organization P-O fit, Person-Job P-J fit and Person-Group (P-G) fit (Judge \& Ferris, 1992; Werbel \& Gilliland, 1999). Previous researches suggest that P-E fit has a positive relationship with individual's job satisfaction, career involvement, organizational commitment and a negative relationship with turnover intention (Bretz \& Judge, 1994; Chatman, 1991; Hollenbeck, 1989). Due to these findings, researchers have tried to differentiate between different types of fit under the key concept of P-E fit and its relationship with turnover intention. This study examines impact of two most common fit concepts i.e. $\mathrm{P}-\mathrm{O}$ fit and P-J fit on employee turnover intention while considering psychological climate as a mediating variable.

For years, turnover remained a topic of considerable interest for organizational scholars because it results in direct as well as indirect cost to the organization. Direct cost is the cost associated with selecting, recruiting and training of new staff (Staw, 1980). This loss of social capital due to turnover of employees, work overload and reduction in the morale of remaining employees results in indirect cost (Dess \& Shaw, 2001). It is very important for the managers to identify the turnover intention of employees so that some course of action can be implemented. An individual's intention to leave the organization will be the actual predictor of turnover as the behavior of an individual is best determined by intention to behave in a particular way according to the theory of planned behavior (Ajzen, 1991).Therefore, it becomes very important to identify the antecedents of turnover intention in order to reduce the actual turnover.

In previous researches P-E fit was considered as an independent variable or predictor which was affecting the dependent variable of employee outcome related variables i.e. turnover. However, in recent years, the researchers have tried to find out some mediating and moderating variables that exist between these relationships (Da Silva, Hutcheson, \& Wahl, 2010; Jelinek \& Ahearne, 2010). The relevant literature suggests psychological climate as an antecedent of various individual outcomes as job satisfaction and turnover (James, James, \& Ashe, 1990).To our knowledge, very few studies exist that try to explore the effect of psychological climate as a mediator between types of P-E fit and turnover intention specially in the context of Pakistan. Psychological climate refers to how employees of an 
organization interprets and perceive their organizational environment. Employees usually decide to quit an organization at some particular time (Baysinger \& Mobley 1983). This can be due to the stress factors that are arising because of incompatibility between the employee's perception of his/her workplace (Mobley 1982). A person better fitted in the work environment is less likely to leave the organization. Literature suggests that psychological climate must be examined as a precursor of various individual level outcomes that include, job involvement, job satisfaction and turnover intentions (James, et al., 1990; Parker et al., 2003; Woodard, Cassill, \& Herr, 1994).Therefore, the current study aims to investigate the relationship between Person-Organization P-O fit, Person-Job P-J fit and turnover intention while considering psychological climate as a mediating variable. There is limited literature that shows the relationship between these variables in the context of Pakistan. This study will help in adding knowledge to the existing body of literature by examining the impact of these variables in the banking sector of Pakistan. It will guide managers of the organizations to understand the phenomena of P-O fit and P-J fit that will help adjusting employees in the organization's climate so as to reduce their turnover intention.

\section{Literature Review}

\subsection{Person-Organization-Fit}

Person-organization $\mathrm{P}-\mathrm{O}$ fit is considered as a topic of great interest in the disciplines of organizational behavior and human resource management. In simple words P-O fit is defined as measure of fit among workers and the organizations (Silverthorne, 2004). In a broader view, P-O fit is defined as matching between distinctive characteristics of the employee and the organization in which that employee is working. P-O fit is a construct that has multiple conceptualizations (Westerman \& Cyr, 2004b). Moreover, P-O fit is evaluated by matching the personality of the individual worker with his or her organization (Cable \& Judge, 1996).P-O fit is the compatibility of characteristics of the individual and that of organization (Chan, 1996). Individual characteristics include individual's ideas, principles, interests and dispositional characteristics while organizational characteristics are made of organizational doctrine, norms, traditions and the overall organizational climate.

$\mathrm{P}-\mathrm{O}$ fit is the level of compatibility that exists between worker and organizations when at the minimum level one entity holds responsible for providing what the other want and prefers (Kristof, 1996). This compatibility is of two types, one is supplementary fit and the other is complementary fit (Kristof, 1996).Supplementary fit means that personal characteristics of the individual employee are harmonized with that of the organizational characteristics. If the workers psychological needs are satisfied by the conditions of the workplace, then complementary fit is achieved. If the employee is better fitted in the organization through having supplementary or complementary fit then the employee will become a satisfied employee (Bright, 2007; Kristof, 1996).

\subsection{Person-Job-Fit}

P-J fit is defined as compatibility that exists between an individual personal attributes and the job characteristics and is of two types: One is Demand-Abilities (D-A) fit while the other is Need-Supply (N-S) fit (Cable \& DeRue, 2002). D-A fit is referred as matching between 
employees Knowledge, Skills and Abilities (KSA) with requirements of their jobs, whereas $\mathrm{N}-\mathrm{S}$ fit can be referred as the degree to which employees needs, aspirations and preferences are fulfilled by the jobs they perform and by the rewards associated with that jobs (Cable \& DeRue, 2002). These two parts of P-J fit are now combined into an overall concept of P-J fit (Cable \& DeRue, 2002; Vogel \& Feldman, 2009). A good fit exists when an individual have right skills and abilities to perform his job or the job can fulfill the individual's need (Edwards, 1991).

\subsection{Psychological Climate}

The term psychological climate is often used to suggest the perceptions about job circumstances in organizational psychology in which attitudes, personality, behavior, motivations, and mindset and core values of an individual influence the organizational performance. Psychological climate can be defined as how the employees interpret and perceive their organizational environment (James , Hater , Gent , \& Bruni 1978; Selmer, 2005). These perceptions are based on employees experience with the organization (Koys \& DeCotiis 1991; Schneider, 1975). It can be associated with individual's emotional states, personality traits and cognitive perceptions (Ward \& Kennedy, 1996). These perceptions are relatively consistent, homogenous and stable over time (Moran \& Volkwein, 1992). Difference in the perception and evaluation of psychological climate is due to individual differences, differences in features of the organization's environment and difference in the interaction between the individual and the working environment (Fred, George , \& J.H, 1975; James, et al., 1990). The construct of psychological climate is divided into six sub-dimensions which are supportive management, contribution, role clarity, recognition, self expression and challenge (Brown \& Leigh 1996).

\subsubsection{Supportive Management}

Supportive managers will allow their subordinates to control their own work activities and methods for accomplishing their tasks without fear of punishment (Brown \& Leigh 1996). The power, freedom of choice and sense of security passed on by managers to their subordinates will increase motivation and results in greater job involvement (Argyris, 1964; Deci \& Ryan, 1985).

\subsubsection{Contribution}

When the employees perceive that their work will significantly contribute in achieving organizational goals, they will become more involved in their jobs (Kahn, 1990a; White, 1959).

\subsubsection{Role Clarity}

Role clarity means that work situations and role expected from employees are predictable, consistent and clear to them. These predictable work standards will create psychologically safe working environment (Brown \& Leigh 1996).

\subsubsection{Recognition}

Perceived meaningfulness of the work environment is increased if one feels that his contribution and efforts are well-recognized and appreciated (Kahn, 1990a, 1990b). 


\subsubsection{Self- Expression}

Employees can express the distinctive elements of their personality if the organizational environment fosters freedom of action (Kiewitz, Hochwarter, Ferris, \& Castro, 2002). Employees who are able to express themselves without fear of reprisals will experience psychological safety (Brown \& Leigh 1996). On the other hand, this safety to express oneself will result in greater job satisfaction (Shalley, Gilson, \& Blum, 2000) greater organizational commitment and reduced turnover intention (Kiewitz, Hochwarter, Ferris, \& Castro, 2002). Employees can express the distinctive elements of their personality if the organizational environment fosters freedom of action.

\subsubsection{Challenge}

Challenging work that requires use of various creative skills will result in perceived meaningfulness of the work and will help employees to achieve personal growth (Hackman \& Oldham, 1980; Kahn, 1990a).

\subsection{Turnover Intention}

Turnover has become a major concern for management in this century because organizations make huge investments on their employees in terms of recruiting, training, developing and retaining them. Turnover intention can be defined as the intention of an employee to quit his current job and discarding of his or her organizational membership (Meyer \& Allen, 1984). Turnover can also be referred as transfer of employees across the organizational boundaries (Macy \& Mirvis, 1976). Various studies consider turnover intention as a major antecedent of turnover (Bluedorn 1982; Mobley W.H., Horner, \& Hollingsworth 1978; Mobley, Griffith, Hand, \& Megline, 1979; Steel \& Ovalle, 1984). Therefore, The researchers always try to identify and deal with turnover intentions so that turnover can be reduced in the organizations. Turnover can be voluntary as well as involuntary. This study considers voluntary turnover in which employees want to leave the organization at their own will either to escape the stress factors associated with the working environment or to take the better advantage of the opportunities in the labor market.

\section{Conceptual Frame work}

Our conceptual framework (see figure 1) expresses the relationship between P-O fit, P-J fit, psychological climate and turnover intention. Psychological climate is considered as a mediating variable in this framework.

\subsection{Person-Organization-Fit and Turnover Intention}

Attention should be paid to the fit of values between the individuals and the organizations in which they are working (Elfenbein \& O'Reilly, 2007). Employees are likely to stay in the organization if they perceive that they are better fitted with their jobs and the organization (Wheeler, Buckley, Halbesleben, Broue , \& Ferris 2005). There will be a higher turnover rate if there is dissatisfaction and inconsistency between the individual and the organizational goals (Lee, Mitchell, Wise, \& Fireman, 1996). Similarly, Person-organization-fit has positive relationship with job satisfaction and negative relationship with turnover intention (Bretz \& Judge, 1994; Harris \& Mossholder 1996). 
Moynihan \& Pandey (2008) studied nine organizations in the United States and their findings also support the above conclusion. High level of P-O fit will increase motivation of employees towards task performance resulting in employee engagement and long lasting

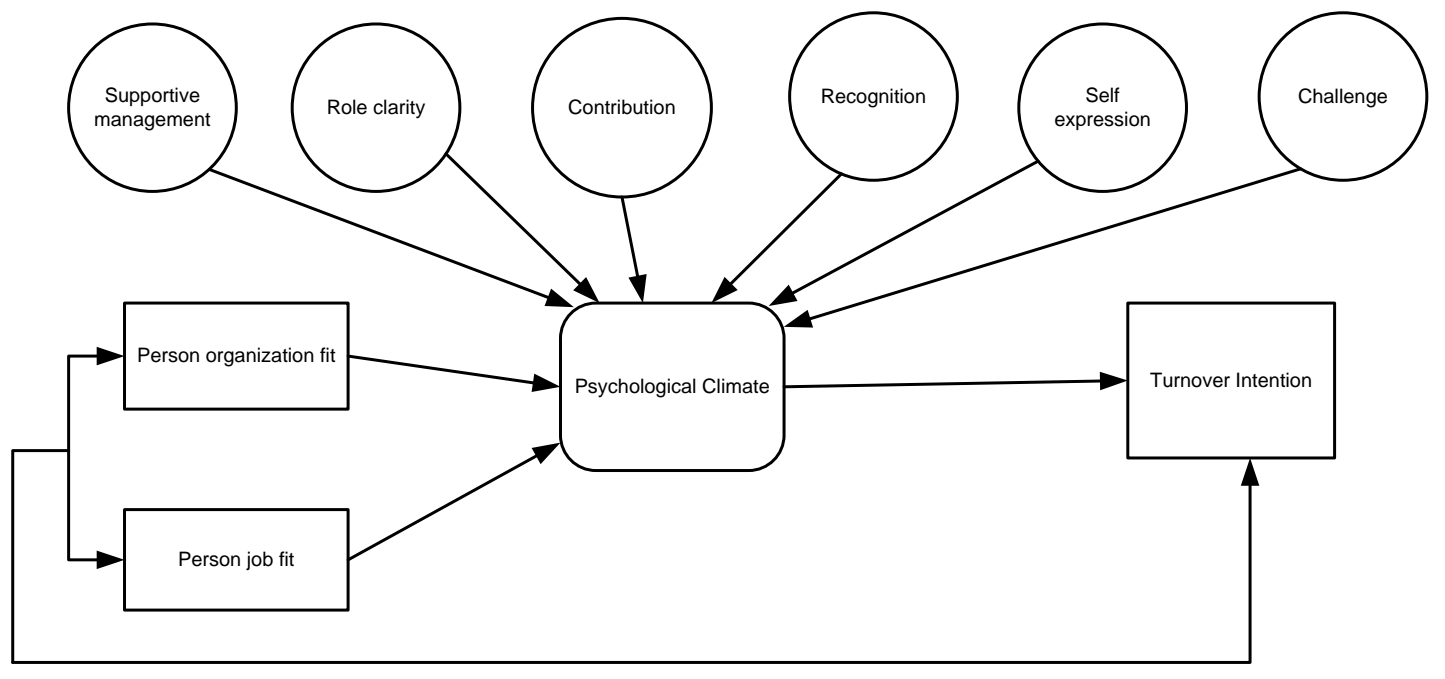

Figure 1: Conceptual framework

relationships with employers (Ballout, 2007). So, we have suggested the following hypothesis in the light of the above mentioned research findings:

H1: Person-organization-fit has negative relationship with turnover intention.

\subsection{Person-Job-Fit and Turnover Intention}

Employees who are better fitted in their organizations are committed and want to remain the part of the organization but will prefer changing their job positions if they are not fitted with their jobs (Saks \& Ashforth 1997). Hollenbeck (1989) conducted an empirical study and concluded that poor person-job-fit will result in job turnover. As, P-J fit is about matching the knowledge, skills and abilities (KSAs) of employees with the demands of the job so lower level of performance, high turnover rate and more absenteeism will result if a good fit does not exists (Mathis \& Jackson, 2003). Individuals who experience a mis-fit between their own abilities and complexities of the job will have an intention to leave their job for another job in which they perceive better fit (Wilk \& Sackett 1996). Increased productivity, job satisfaction, organizational commitment and reduced turnover intention becomes apparent as the congruence between an individual and an organization or a job increases (Iplik, Kilic, \& Yalcin, 2011). On the basis of these findings we suggested following hypothesis:

H2: Person- job-fit has negative relationship with turnover intention.

\subsection{Psychological Climate as a Mediator}

Psychological climate perception is perception about different features of the work environment as supporting relationships from the co-workers and supervisor (Schneider \& Reichers 1983; Tordera, Vicente, \& Peiró, 2008). Factors that are related with supportive management (i.e. supervisor's support \& organizational support) and job clarity will have negative relationship with turnover intention (Dupré \& Day, 2007). Socio-psychological 
perspective of employee attitude suggests that intention to stay or leave the organization is a response that can arise due to stress factor resulting from inconsistencies between perceptions of the psychological climate on one hand and need and aspirations of the employees on the other hand (Mobley 1982). As discussed above, a person better fitted in the organization will have less intention to leave the organization (Wheeler et al., 2005). Similarly person-job-misfit also leads to employee turnover (Wilk \& Sackett 1996). Hom \& Griffeth (1995) suggested that precursor of turnover often function through the mediating variables and will influence employees turnover intention and according to Westerman \& Cyr (2004a), working attitudes mediates the relationship of P-O fit and turnover intention. In the light of above research findings we have developed following hypotheses and included psychological climate as a mediator between person-organization fit, person-job-fit and turnover intention.

H3: Psychological climate mediates the relationship between person-organization-fit and turnover intention

H4: Psychological climate mediates the relationship between person-job-fit and turnover intention.

\section{Methodology}

\subsection{Data Collection\& Measurement Scale}

The main variables of the study were person-organization-fit, person-job-fit, psychological climate and turnover intention. Standard questions are used to measure these variables which are adopted from previous studies. Data used in the current study is collected from employees of top five commercial banks of large cities of Pakistan. Total of 300 questionnaires were distributed out of which 260 were returned showing response rate of $86 \%$. Respondents were asked to show their response on 5-point Likert scale ranging from $1=$ strongly disagree to $5=$ strongly agree. P-O fit was measured by using five item scale that is adopted from previous researches (Edwards, 1991; Valentine, Godkin, \& Lucero, 2002) having alpha reliability $=.91$. P-J fit was measured using five item scale adopted from (Kristy, Lauver, \& Kristof-Brown, 2001). Alpha reliability of this scale is .79. Psychological climate was measured using scale adopted from (Brown \& Leigh 1996) having alpha=.82. This scale is composed of six factors supportive management ( 5 items), role clarity ( 3 items), contribution (4 item), recognition (3 items), self-expression (4 items), and challenge ( 2 items). Respondent turnover intention was measured using the scale adopted from Seashore \& Cammann (1982) having reliability $=.90$. Data is analyzed by using the Statistical Package for Social Science version 17 (SPSS17). Principle component factor analysis with varimax rotation was performed for all four measurement scales. The results are shown in table 1, $2 \& 3$. As per suggestions of (Field, 2005), to test the validity of scale items principle component factor analysis is the appropriate method. Results in Table 1 show two factor solutions: First factor P-O fit, (two items have been removed out of 5 items due to low loading). Second factor P-J fit (two items have been removed out of 5 items due to high cross loading. Psychological climate dimension was extracted on six factor solution. Turnover intention was extracted on one factor solution. All the items loaded substantially on the extracted factor. After performing the factor analysis, data is also tested for reliability by using Cronbach's alpha 
coefficient. All the scales which were used to measure the key variables of study have acceptable level of reliability, which is greater than 0.70 as suggested by (Nunnally, 1967).

Table 1: Factor Analysis \& Cronbach's alpha: P-O Fit \& P-J Fit

\begin{tabular}{|c|c|c|}
\hline \multirow{2}{*}{$\begin{array}{l}\text { Construct items \& Cronbach's alpha } \\
\text { 1.Person-Organization Fit }(\alpha=0.799)\end{array}$} & \multicolumn{2}{|c|}{$\begin{array}{l}\text { Standardized Factor Loadings } \\
\text { Factors }\end{array}$} \\
\hline & 1 & 2 \\
\hline $\begin{array}{l}\text { 1. My organization meets my major needs well. } \\
\text { 2. This organization has the same values as I do with regard to } \\
\text { concern for others } \\
\text { 3. I feel that my personal values are a good fit with this } \\
\text { organization }\end{array}$ & $\begin{array}{l}0.863 \\
0.847 \\
0.737\end{array}$ & \\
\hline \multicolumn{3}{|l|}{ 2:Person-Job-Fit $(\alpha=0.797)$} \\
\hline $\begin{array}{l}\text { 1. I am the right type of person for this type of work. } \\
\text { 2. My personality is a good match for this job. } \\
\text { 3. There is a good match between the requirements of this job } \\
\text { and my skills }\end{array}$ & & $\begin{array}{l}0.905 \\
0.835 \\
0.626\end{array}$ \\
\hline Cumulative percentage of the variance explained (\%) & 39.4 & 73.2 \\
\hline
\end{tabular}

Table 2: Factor Analysis \& Cronbach's alpha: Psychological Climate

\begin{tabular}{|c|c|c|c|c|c|c|}
\hline 3.Pyschological Climate Items & \multicolumn{6}{|c|}{ Factors } \\
\hline 3.1.Supportive Management $(\alpha=0.821)$ & 1 & 2 & 3 & 4 & 5 & 6 \\
\hline $\begin{array}{l}\text { 1. My manager Is supportive of my ideas and } \\
\text { ways of getting things done } \\
\text { 2. My Boss is flexible about how I accomplish } \\
\text { my job objectives. } \\
\text { 3. My Boss gives me authority to do my job } \\
\text { as I see fit } \\
\text { 4. I can trust my boss to back me up on } \\
\text { decision I make in the field. }\end{array}$ & $\begin{array}{l}0.823 \\
0.757 \\
0.668\end{array}$ & & & & & \\
\hline 3.2.Role Clarity $\alpha=(0.850)$ & & & & & & \\
\hline
\end{tabular}


1. The amount of work responsibility and effort expected in my job is clearly defined.

2. The norms of performance in my department are well understood and communicated.

3.3. Contribution $(\alpha=0.830)$

1. I feel like a key member of the organization

2.Doing my job well really makes a difference

3. The work I do is very valuable to the organization

4. I feel very useful in my job

3.4.Recognition $(\alpha=0.819)$

1. My superiors generally appreciated the way I do my job

2. The organization recognizes the significance of the Contributions I make.

3.5.Self-Expression $(\alpha=0.822)$

1. There are parts of myself that I am not free to express at work.

2. I feel free to be completely myself at work

3. The feelings I express at work are my true feelings.

3.6. Challenge $(\alpha=0.705)$

1. My job is very challenging.

2. It takes all of my resources to achieve my work objectives. 
Cumulative percentage of the variance 14.9 \begin{tabular}{l|l}
28.7 & 42
\end{tabular} 55.1 explained $(\%)$

Table 3: Factor Analysis \& Cronbach's alpha: Turnover Intention

\begin{tabular}{|l|l|}
\hline Construct items \& Cronbach's alpha & Standardized Factor Loadings \\
\hline Turnover Intention $(\alpha=0.911)$ & \multicolumn{1}{|c|}{ Factor } \\
\hline $\begin{array}{l}\text { 1. I am currently seriously considering leaving my current job to } \\
\text { work at another company }\end{array}$ & 0.915 \\
$\begin{array}{l}\text { 2. I will quit this company if the given condition gets even a } \\
\text { little worse than now }\end{array}$ & 0.900 \\
$\begin{array}{l}\text { 3. I will quit my job at my current organization in 1 year or less. } \\
\text { 4. I will quit my job at my current organization in 1 year or less }\end{array}$ & 0.872 \\
\hline Cumulative percentage of the variance explained (\%) & 79.0 \\
\hline
\end{tabular}

\section{Results}

\subsection{Correlation Analysis}

Our conceptual framework shows the relationships between person-organization-fit, person-job-fit, psychological climate and turnover intention. To test this relationship correlation analysis is performed. Table 4 shows the mean values, standard deviations and correlation matrix for the key variables of this study. We have computed average score of sub-dimensions of psychological climate as computed by other researchers (i.e. (Farukh 2011; Soumendu Biswas., 2010) for performing correlation and regression analysis. The matrix shows that there is significant negative correlation between $\mathrm{P}-\mathrm{O}$ fit and turnover intention $(\mathrm{r}=$ -.513, $\mathrm{p}<0.01)$, between P-J fit and turnover intention $(\mathrm{r}=-.395, \mathrm{p}<0.01)$, and between psychological climate and turnover intention $(r=-.487, p<0.01)$. The correlation matrix also shows the significant positive correlation between P-J fit, P-O fit, and psychological climate .Therefore, this strong correlation among the variables confirms our all hypotheses initially. For testing the impact of P-J fit and P-O fit on psychological climate and on turnover intention and to test the mediating effect of psychological climate between P-O fit, P-J fit and turnover intention we have performed regression analysis.

Table 4: Variable \& Correlation Matrix

\begin{tabular}{|l|l|l|l|l|l|l|}
\hline Variable & Mean & S.D & 1 & 2 & 3 & 4 \\
\hline POF & 3.75 & .849 & 1 & - & - & - \\
\hline PJF & 3.74 & .897 & $0.512 * *$ & 1 & - & - \\
\hline PC & 3.78 & .664 & $0.618 * *$ & $0.525 * *$ & 1 & - \\
\hline TO & 2.8 & .991 & $-0.513 * *$ & $-0.395 * *$ & $-0.487 * *$ & 1 \\
\hline
\end{tabular}

Note: **Correlation is significant at the 0.01 level (2-tailed); POF =Person Organization Fit; 
$\mathrm{PJF}=$ Person-job-Fit; $\mathrm{PC}=$ Psychological Climate; $\mathrm{TO}=$ Turnover Intention

\subsection{Regression Analysis}

Regression Analysis was carried out in order to test the extent of impact of independent variables on dependent variable and the full or partial mediating effect of psychological climate. According to Baron \& Kenny (1986), following conditions should be met if we want to test the mediating effect of a certain variable: First, Independent and mediating variable must be significantly related. Second, there must be a significant relationship between independent variable and dependent variable. Third, when the mediating variable is introduced the impact on dependent variable by independent variable will significantly decrease. We have used the same method of regression analysis that was suggested by Baron\& Kenny (1986) to perform mediation effect. Results of Regression Analysis are shown in Table 5. As indicated in the first step, Adjusted $\mathrm{R}^{2}$ is .436 which shows that variation in psychological climate is explained up to $43 \%$ through variation in independent variables. Standard regression coefficient between $\mathrm{P}-\mathrm{O}$ fit and psychological climate is significant ( $\beta=.474, \mathrm{p}<.001)$ with significant $\mathrm{T}$ value $(8.691, \mathrm{p}<.001)$ and $\mathrm{F}$ value $(100.518, \mathrm{p}<.001)$. Standard regression coefficient between P-J fit and psychological climate is also significant $\beta=.282, \mathrm{p}<.001)$ with significant $\mathrm{T}$ and $\mathrm{F}$ values i.e. $5.172(\mathrm{p}<.001)$ and $100.518(\mathrm{p}<.001)$ respectively. In the second step, Adjusted $\mathrm{R}^{2}$ is .287 indicating that the variation in turnover intention is explained up to $28 \%$ through variation in independent variables. Standard regression coefficient between $\mathrm{P}-\mathrm{O}$ fit and turnover intention is significant $(\beta=-.421, \mathrm{p}<.001$ ) with significant $\mathrm{T}$ value $(6.843, \mathrm{p}<.001)$ and $\mathrm{F}$ value $(51.345, \mathrm{p}<.001)$. Standard regression coefficient between P-J fit and turnover intention is also significant $(\beta=-.179, \mathrm{p}<.001)$ with significant $\mathrm{T}$ value $(2.914, \mathrm{p}<.001)$ and $\mathrm{F}$ value $(51.345, \mathrm{p}<.001)$. In the third step, Psychological climate is added into the overall model of P-O fit, P-J fit and turnover intention. The results indicate that standard regression coefficient in case of $\mathrm{P}-\mathrm{O}$ fit has decreased in magnitude but still is significant $(\beta=-.309, \mathrm{p}<.001)$; however, in case of P-J fit, it has not only decreased in magnitude but also become non significant $(\beta=-.112, \mathrm{p}=.078)$. Hence, psychological climate partially mediates the relationship between person-organization-fit and turnover intention but fully mediates the relationship between person-job-fit and turnover intention. So, H 4 and H5 are well supported.

To further support the proposed mediation model, we also conducted Sobel (1982) test as suggested by Baron \& Kenny (1986). This test is conducted to see the effect of mediating variable (psychological climate) on dependent variable (Turnover) intention. Computed $\mathrm{p}$ values are significant which show the support for mediation. 
Table 5: Regression Analyses:

\begin{tabular}{|c|c|c|c|c|c|c|c|c|}
\hline Step & $\begin{array}{l}\text { Dependent } \\
\text { Variable }\end{array}$ & $\begin{array}{l}\text { Independent } \\
\text { Variable }\end{array}$ & $\begin{array}{l}\text { Standardized } \\
\text { regression } \\
\text { coefficients }\end{array}$ & $\mathrm{F}$ & $\mathrm{T}$ & Sig. & $\begin{array}{l}\text { Adjusted } \\
\mathrm{R}^{2}\end{array}$ & Result \\
\hline 1 & $\mathrm{PC}$ & $\begin{array}{l}\text { POF } \\
\text { PJF }\end{array}$ & $\begin{array}{l}.474 \\
.282\end{array}$ & 100.58 & $\begin{array}{l}8.691 \\
5.172\end{array}$ & $\begin{array}{l}.000 \\
.000\end{array}$ & .436 & \\
\hline 2 & TO & $\begin{array}{l}\text { POF } \\
\text { PJF }\end{array}$ & $\begin{array}{l}-.421 \\
-.179\end{array}$ & 51.345 & $\begin{array}{l}6.843 \\
2.914\end{array}$ & $\begin{array}{l}.000 \\
.004\end{array}$ & .287 & \\
\hline \multirow[t]{2}{*}{3} & \multirow[t]{2}{*}{ TO } & $\begin{array}{l}\text { POF } \\
\text { PJF }\end{array}$ & $\begin{array}{l}-.421 \\
-.179 \\
\end{array}$ & 51.345 & $\begin{array}{l}6.843 \\
2.914 \\
\end{array}$ & $\begin{array}{l}.000 \\
.004 \\
\end{array}$ & .287 & \\
\hline & & $\begin{array}{l}\text { POF } \\
\text { PJF } \\
\text { PC }\end{array}$ & $\begin{array}{l}-.309 \\
-.112 \\
-.238\end{array}$ & 39.59 & $\begin{array}{l}4.495 \\
1.772 \\
3.443\end{array}$ & $\begin{array}{l}.000 \\
.078 \\
.001\end{array}$ & .319 & $\begin{array}{l}\text { Partial } \\
\text { Mediation } \\
\text { Full } \\
\text { Mediation }\end{array}$ \\
\hline
\end{tabular}

POF =Person Organization Fit, PJF = Person-job-Fit, PC = Psychological Climate,

$\mathrm{TO}=$ Turnover Intention, Sobel Test is significant $(\mathrm{P}<0.001)$

\section{Discussion \& Conclusion}

Employee turnover intentions have negative influence on organizational performance (Reiche, 2008; Shaw , Gupta, \& Delery 2005). Since employees are the most valuable asset for an organization, managers always try to identify the factors causing turnover intention in their organization. The current study examined the impact of P-O fit and P-J fit on employee turnover intention while considering psychological climate as a mediating variable. First, our empirical analysis demonstrates the relationship between $\mathrm{P}-\mathrm{O}$ fit and turnover intention. A significant negative relationship is proved between these two variables. This finding is in accordance with the earlier researches (Becker \& Billings 1993; Bretz \& Judge, 1994; Brown \& Yoshioka, 2003; Edwards, et al., 1998; Harris \& Mossholder 1996; Lee, et al., 1996; Verquer, Beehr, \& Wagner, 2003), which implies that employees who are better fitted in their organizations have less intention to leave. Secondly, this study empirically tested the relationship between person-job-fit and turnover intention. The results of empirical analysis show that these two variables are also significantly negatively correlated. This finding is also supporting the earlier work(Hollenbeck 1989; Saks \& Ashforth 1997; Wilk \& Sackett 1996), which implies that the employees who have such knowledge, skills and abilities that are better aligned with their jobs have less intention to leave their jobs. Thirdly, the study tests mediating relationship of psychological climate between P-O fit, P-J fit and turnover intention. The results suggest that psychological climate fully mediates the relationship between P-J fit and turnover and partially mediates the relationship between P-O fit and turnover.

\section{Theoretical Implications:}

Previous researches tested the relationship between psychological climate and turnover intention but to our knowledge, no significant research is conducted to test the mediating 
effect of psychological climate between P-O fit, P-J fit and turnover intention especially in the context of Pakistan. Moreover, previous studies have only assessed one type of fit while this study asses the impact of both P-O fit \& P-J fit on turnover intention because it provides a more realistic picture by considering the influence of both types of fit on employee turnover intention.

\section{Managerial Implications:}

The current study will contribute both theoretically and practically by helping the managers of banking sector of Pakistan to curtail a considerable turnover ratio by understanding the underlying phenomena of P-O fit, P-J fit, turnover intention and psychological climate. P-O fit and P-J fit can be seen as an important tool for managing human resource processes as they play an important role in selecting, socializing and training of workforce that can become the source of competitive advantage for the organization. So, the managers should focus on selecting such employees whose personality and values are in congruence with that of the organization and with their jobs. The selection of right type of person for right type of job will improve productivity of the organization and will reduce turnover intention. Managers must also consider the perception of employees about their work environment. In this regard number of factors must be considered such as management should be supportive one defining clear, consistent and predictable roles for their employees. Moreover a climate of expression should be provided to the individuals where their efforts and contributions must be recognized. This will result in better psychologically adjustment in the organization and reduced turnover intentions.

\section{Limitations \& Future Scope of Research}

This study has certain limitations as well. This study investigated the impact of P-O fit and P-J fit on turnover intention only in the banking sector of Pakistan. An additional insight can be provided by investigating the relationship of these variables in the other economic sectors as well. More integrative theoretical and empirical work is needed for a continued progress to be made on fit measures that can include the other types of fit as well e.g. person-group (P-G) fit and person-vocation $(\mathrm{P}-\mathrm{V})$ fit. Research can also be done in cross-cultural context and lot of research opportunities exists to study the impact of different types of person-environment (P-E) fit on different individual and organizational outcomes.

\section{References}

Ajzen, I. (1991). The theory of planned behavior. Organizational Behavior and Human Decision Processes, 50(2), 179-211.

Argyris, C. (1964). Integrating the individual and the organization. New York: Wiley.

Ballout, H. I. (2007). Career success: the effects of human capital, person-environment fit and organizational support,. Journal of Managerial Psychology, 22(8), 741-765.

Baysinger, B. D., \& Mobley, W. H. (1983). Employee turnover: individual and organizational analysis (Vol. 1). Greenwich: CT: JAI Press.

Becker, T. E., \& Billings , R. S. (1993). Profiles of commitment: An empirical test. Journal of Organizational Behavior, 14(2), 177-190. 
Bluedorn, A. C. (1982). A Unified Model of Turnover From Organizations. Human Relations, 35(2), $135-153$.

Bretz , R. D., \& Judge, T. A. (1994). Person-organization fit and the theory of work adjustment: implications for satisfaction, tenure and career success. Journal of Vocational Behavior, 44(1), 32-54.

Bright, L. (2007). Does person-organization fit mediate the relationship between public service motivation and the job performance of public employees? Review of Public Personnel Administration, 27(4), 361-379.

Brown, S. P., \& Leigh , T. W. (1996). A New Look at Psychological Climate and Its Relationship to Job Involvement, Effort, and Performance. Journal of Applied Psychology, 81(4), 358-368.

Brown, W. A., \& Yoshioka, C. F. (2003). Mission attachment and satisfaction as factors in employee retention. Nonprofit Management and Leadership, 14(1), 5-18.

Cable, \& Judge. (1996). Person-Organization Fit, Job Choice Decisions, and Organizational Entry. Organizational Behavior and Human Decision Processes, 67(3), 294-311.

Cable , D. M., \& DeRue, D. S. (2002). The convergent and discriminant validity of subjective fit perceptions. Journal of Applied Psychology, 87(5), 875-884.

Chan, D. (1996). Cognitive Misfit of Problem-Solving Style at Work: A Facet of Person-Organization Fit. Organizational Behavior and Human Decision Processes, 68(3), 194-207.

Chatman, J. (1991). Matching people and Organizations: Selection and Socialization in Public Accounting Firms. Administrative Science Quarterly, 36(3), 459-484.

Da Silva, N., Hutcheson, J., \& Wahl, G. (2010). Organizational strategy and employee outcomes: A person-organization fit perspective. The Journal of Psychology, 144(2), 145-161.

Dawis, R. V. (1992). Person-environment fit and job satisfaction.In C. J. Cranny, P. C. Smith, \& E. F. Stone (Eds.),Job satisfaction. New York: Lexington

Deci, E. L., \& Ryan, R. M. (1985). Intrinsic motivation and self-determination in human behavior. New York: Plenum.

Dess, G. G., \& Shaw, J. D. (2001). Voluntary turnover, social capital, and organizational performance. Academy of Management Review, 26(3), 466-456.

Dupré, K. E., \& Day, A. L. (2007). The effects of supportive management and job quality on the turnover intentions and health of military personnel. Human Resource Management, 46(2), 185-201.

Edwards, J. R. (1991). Person-job fit: A conceptual integration, literature review, and methodological critique (Vol. 6). New York: Wiley.

Edwards, J. R., Caplan, R. D., \& Harrison, R. V. (1998). Person-environment fit theory: Conceptual foundations, empirical evidence, and directions for future research.In C. L. Cooper (Ed.), Theories of organizational stress. Oxford: Oxford University Press

Elfenbein, H. A., \& O'Reilly, C. A. (2007). Fitting in: The effects of relational demography and person-culture fit on group process and performance. Group and Organization Management, 32(1), $109-142$.

Farukh, S. (2011). Affective Commitment as a mediator of Relationship between Pyschological climate and Turnover intention. Word Applied Science Journal, 14(4), 523-530.

Field, A. (2005). Discovering Statistics Using SPSS (2nd ed.). London: Sage.F. 
Fred , D. J., George , G., \& J.H, W. (1975). A vertical dyad linkage approach to leadership within formal organizations: A longitudinal investigation of the role making process. Organizational Behavior and Human Performance, 13(1), 46-78.

Hackman, J. R., \& Oldham, G. R. (1980). Work redesign: Reading, Mass: Addison-Wesley.

Harris , S. G., \& Mossholder , K. W. (1996). The affective implications of perceived congruence with culture dimensions during organizational transformation. Journal of Management, 22(4), 527-548.

Hollenbeck, J. R. (1989). Control theory and the perception of work environments: The effects of focus of attention on affective and behavioral reactions to work Organizational Behavior and Human Decision Process, 43(3), 406-430.

Hollenbeck , J. R. (1989). Control theory and the perception of work environments: The effects of focus of attention on affective and behavioral reactions to work. Organizational Behavior and Human Decision Process, 43(3), 406-430.

Hom, P. W., \& Griffeth, R. (1995). Employee turnover. Cincinnati, OH: Southwestern.

Iplik, F. N., Kilic, K. C., \& Yalcin, A. (2011). The simultaneous effects of person-organization and person-job fit on Turkish hotel managers. International Journal of Contemporary Hospitality Management, 23(5), 644-661.

James , L. R., Hater , J. J., Gent , M. J., \& Bruni , J. R. (1978). psychological climate:implications from cognitive social learning theory and interactional psychology. Personnel Psychology, 31(40), 783-813.

James, L. R., James, L. A., \& Ashe, D. K. J. (1990). "The Meaning of Organizations: The Role of Cognition and Values"In Benjamin Schneider (Ed.), Organizational Climate and Culture. San Francisco,: CA: Jossey Bass.

Jelinek, R., \& Ahearne, M. (2010). Be careful what you look for: the effect of trait competitiveness and long hours on salesperson deviance and whether meaningfulness of work matters. Journal of Marketing Theory and Practice, 18(4), 303-321.

Judge, T. A., \& Ferris, G. R. (1992). The elusive criterion of fit in human resources staffing decisions

Human Resources Planning, 15(4), 47-67.

Kahn, W. A. (1990a). Psychological conditions of personal engagement and disengagement at work. Academy of Management Journal, 33(4), 692-724.

Kahn, W. A. (1990b). Psychological conditions of personal engagement and disengagement at work. . Academy of Management Journal,, 33, 692-724.

Kiewitz, C., Hochwarter, W. A., Ferris, G. R., \& Castro, S. L. (2002). The role of psychological climate in neutralizing the effects of organizational politics on work

outcomes. Journal of Applied Social Psychology, 32(6), 1189-1207.

Kiewitz , C., Hochwarter, W. A., Ferris, G. R., \& Castro, S. L. (2002). The Role of Psychological Climate in Neutralizing the Effects of Organizational Politics on Work Outcomes. Journal of Applied Social Psychology, 32(6), 1189-1207.

Koys, D. J., \& DeCotiis , T. A. (1991). Inductive measures of psychological climate. Human Relations, 44(3), 49-58.

Kristof, A. L. (1996). Person-organization fit:An integrative review of its conceptualizations,measutement and implications. Personnel Psychology, 49(1), 1-49.

Kristy , J., Lauver, J., \& Kristof-Brown, A. (2001). Distinguishing between Employees' Perceptions of Person-Job and Person-Organization Fit. Journal of Vocational Behavior, 59, 454-470. 
Lee, T. W., Mitchell, T. R., Wise, L., \& Fireman, S. (1996). An Unfolding Model of Voluntary Employee Turnover. Academy of Management Journal 39 (1), 5-36.

Macy, B. A., \& Mirvis, P. H. (1976). A methodology assessment of quality of work life and organizational effectiveness in behavioral-economic terms. Administrative Science Quarterly 21 (2), 212-226.

Mathis, R. L., \& Jackson, J. H. (2003). Human Resource Management.10th Edition. Ohio:Thomson-Southwestern, . USA.

Meyer, J. P., \& Allen, N. J. (1984). Testing the side-bet theory of organizational commitment:some methodological considerations. journal of Applied Psychology, 69(3), 372-378.

Mobley W.H., Horner, S. O., \& Hollingsworth , A. T. (1978). An evaluation of precursors of hospital employee turnover process. journal of Applied Psychology, 63(4), 408-414.

Mobley , W. H. (1982). Employee turnover: Causes, consequences and control. Philippines: Addison-Wesley Publishing.

Mobley, W. H., Griffith, R. W., Hand, H. H., \& Megline, B. M. (1979). Review and conceptual analysis of the employee turnover process. Psychological Bulletin, 86(3), 493-522.

Moran, E. T., \& Volkwein, J. F. (1992). The cultural approach to the formation of organizational climate. Human Relations, 45(1), 19-47.

Nunnally, J. C. (1967). Psychometric Theory (3rd ed.). New York: McGraw-Hill.

Parker, C. P., Baltes, B. B., Young, S. A., Huff, J. W., Altmann, R. A., LaCost, H. A., et al. (2003). Relationships between psychological climate perceptions and work outcomes: a meta-analytic review. Journal of Organizational Behavior, 24(4), 389-416.

Reiche, B. S. (2008). The configuration of employee retention practices in multinational corporations' foreign subsidiaries. International Business Review, 17(6), 676-687.

Saks , A. M., \& Ashforth , B. E. (1997). A longitudinal investigation of the relationships between job information sources,applicant perceptions of fit, and work outcomes. Personnel Psychology, 50(2), 395-426.

Schneider, B. (1975). organizationsal climates : An essay 1. Personnel Psychology, 28(4), 447-479.

Schneider , B., \& Reichers , A. (1983). On the etiology of climates. Personnel Psychology, 36(1), 19-39.

Selmer, J. (2005). Cross-cultural training and expatriate adjustment in China: western joint venture managers. Personnel Review, 34(1), 68-84.

Shalley, C. E., Gilson, L., \& Blum, T. C. (2000). Matching creativity requirements and the work environment: Effects on satisfaction and intentions to leave. Academy of Management Journal, 43(2), 215-223.

Shaw , J. D., Gupta, N., \& Delery , J. D. (2005). Alternative conceptualizations of the relationship between voluntary turnover and organizational performance. Academy of Management Journal, 48, 50-68.

Silverthorne, C. (2004). The impact of organizational culture and person organization fit on organizational commitment and job satisfaction in Taiwan". The Leadership \& Organization Development Journal, 25(7), 529-529.

Soumendu Biswas. (2010). Relationship between psychological climate and turnover intentions and its impact on organisational effectiveness: A study in Indian organisations. Management Review, 22(3), 102-110.

Staw, B. M. (1980). The consequences of turnover. journal of Occupational Behaviour, 1(4), 253-273.

Steel , R. P., \& Ovalle, N. K. (1984). A review and meta-analysis of research on the relationship between behavioural intentions and employee turnover. journal of Applied Psychology, 69(4), 673-686. 
Tordera, N., Vicente, G. R., \& Peiró, J. M. (2008). The moderator effect of psychological climate on the relationship between leader-member exchange (LMX) quality and role overload. European Journal of Work and Organizational Psychology, 17(1), 55-72.

Valentine, S., Godkin, L., \& Lucero, M. (2002). Ethical context, organizational commitment and person-organization fit. Journal of Business Ethics, 41(4), 349-360.

Verquer, M. L., Beehr, T. A., \& Wagner, S. H. (2003). A meta-analysis of relations between person-organization fit and work attitudes. Journal of Vocational Behavior, 63(3), 473-489.

Vogel, R. M., \& Feldman, D. C. (2009). Integrating the levels of person-environment fit: The roles of vocational fit and group fit. Journal of Vocational Behavior, 75(1), 68-81.

Ward , C., \& Kennedy, A. (1996). Crossing cultures: the relationship between psychological and socio-cultural dimensions of cross-cultural adjustment. New Delhi: Sage Publications.

Werbel, J. D., \& Gilliland, S. W. (1999). Person-environment fit in the selection process. Research in personnel and human resources management, 17, 209-243.

Westerman, J. W., \& Cyr, L. A. (2004a). An integrative analysis of person-organization fit theories. International Journal of Selection and Assessment, 12, 252-261.

Westerman, J. W., \& Cyr, L. A. (2004b). An Integrative Analysis of Person-Organization Fit Theories. International Journal of Selection and Assessment, 12(3), 252-261.

Wheeler, A. R., Buckley , M. R., Halbesleben , J. R., Broue , R. L., \& Ferris , G. R. (2005). The elusive criterion of fit revisited: Toward an integrative theory of multidimensional fi. Greenwich,: JAI Press.

White, R. W. (1959). Motivation reconsidered: The concept of competence. Psychological Review, 66(5), 297-333.

Wilk, S. L., \& Sackett , P. R. (1996). Longitudinal analysis of ability-job complexity fit and job change. Personnel Psychology, 49(4), 937-967.

Woodard, G., Cassill, N., \& Herr, D. (1994). The Relationship between Psychological Climate and Work Motivation in a Retail Environment. NewYork: Routledge 